\title{
Effect of an acid mine spill on soils in Sonora River Basin: Micromorphological indicators
}

\section{AUTHORS}

\section{Rivera-Uria}

M.Y.@

petuzza@gmail.com

\section{Ziegler-Rivera F.}

R.A.

Díaz-Ortega J.

Prado-Pano B.

Martín Romero F.

@ Corresponding Author

Instituto de Geología, Universidad Nacional Autónoma de México, UNAM, CU. 04510

Ciudad de México, México.

\author{
Efecto de un vertido ácido minero sobre suelos en la Cuenca del Río Sonora: indicadores \\ micromorfológicos \\ Efeito de um derrame mineiro ácido em solos da Bacia do Rio Sonora: indicadores \\ micromorfológicos
}

Received: 01.05.2017 | Revised: 05.04.2018 | Accepted: 22.05.2018

\section{ABSTRACT}

The role of soil could be decisive for the neutralization of the acid solution and immobilization of the metallic contaminants produced by mining industry. We studied micromorphological indicators of the interaction between the acid solution and soil material in the profile of Fluvisol at the Bacanuchi river (Sonora River Basin, Mexico) terrace affected by the catastrophic mine spill and in analyzing sample from a soil column treated with an acid liquid imitating the spill. Original unaffected soil is sandy with poorly developed pedogenetic features, however, frequent primary and secondary micritic and sparitic carbonates define high $\mathrm{pH}$ values. In the soil influenced by acid solutions under natural and laboratory conditions, carbonates were absent whereas neoformed gypsum crystals with radial intergrowth were observed together with accumulation of fine material enriched in ferruginous pigment. Micromorphometric quantification of the iron-rich fine material has shown its increase after interaction with the acid solution. We conclude that the interaction consisted of the neutralization reaction between the more reactive phases of the soil and the acid solution during which carbonates were consumed and gypsum was neoformed. Fine iron oxides precipitated after neutralization of acidity, the $\mathrm{pH}$ increased and the color changed. It is highly probable that other metallic contaminants co-precipitated with the ferruginous components.

\section{RESUMEN}

El papel del suelo podría ser decisivo en la neutralización de la solución acida y la inmovilización de los contaminantes metálicos producidos por la industria minera. Se estudiaron indicadores micromorfológicos de la interacción entre la solución acida y material edáfico de un Fluvisol del rio Bacanuchi (Cuenca del Rio Sonora, México), terraza afectada por el derrame de la mina, y muestra de una columna de suelo tratada con la solución acida imitando el derrame. El suelo original no afectado es arenoso con características pedogenéticas poco desarrolladas; sin embargo, presenta abundantes carbonatos primarios y secundarios de tamaño micrítico y esparítico con valores altos de $\mathrm{pH}$. En el suelo afectado por la solución ácida bajo condiciones naturales y de laboratorio ya no se encuentran los carbonatos mientras que se observaron minerales neoformados de yeso con intercrecimiento radial junto con material fino ferruginoso. La cuantificación micromorfológica del material fino rico en hierro ha demostrado su aumento después de la interacción con la solución ácida. Concluimos que la interacción consistió en la reacción de la neutralización entre las fases más reactivas del suelo y la solución ácida durante la cual se consumieron los carbonatos y se produjo la neoformación del yeso. Después de la neutralización precipitaron óxidos de bierro finos, aumentó el pH y cambió el color del suelo. Es altamente probable que otros contaminantes metálicos co-precipitaran con los componentes ferruginosos. 


\section{RESUMO}

O papel do solo poderá ser decisivo na neutralização da solução ácida e na imobilização dos contaminantes metálicos produzidos pela indústria mineira. Estudaram-se indicadores micromorfológicos resultantes da interação entre a solução ácida es constituintes de um Fluvissolo do terraço do rio Bacanuchi (Bacia do Rio Sonora, México) afetado pelo derrame mineiro e uma amostra de uma coluna de solo tratada com uma solução ácida para imitar o derrame. O solo original não afetado é arenoso com características pedogenéticas pouco desenvolvidas; contudo, apresenta abundantes carbonatos primários e secundários micríticos e esparíticos e elevado valor de pH. No solo afetado pela solução ácida, em condições naturais e de laboratório, não se observaram carbonatos, mas foram observados cristais de gesso de neoformação com crescimento radial juntamente com material fino ferruginoso. A quantificação micromorfológica do material fino rico em ferro mostrou o seu aumento após interação com a solução ácida. Conclui-se que a interação consistiu numa reação de neutralização entre as fases mais reativas do solo e a solução ácida durante a qual os carbonatos foram consumidos e o gesso foi neoformado. Depois da neutralização, precipitaram óxidos de ferro finos, aumentou o valor do pH e a cor do solo foi alterada. É altamente provável que outros contaminantes metálicos ten ham coprecipitado com os componentes ferruginosos.

\section{Introduction}

Copper is a metal that has been used by man for 5 thousand years, at the present time it is widely used in modern industry. The predominant kind of extraction is the surface mining that drastically transforms the local environment. The mining operations can have physical, chemical and biological effects on soil and rock (solid phase), groundwater and surface water (liquid phase) and air and pore gases (gaseous phase) (Morin and Hutt 2001).

An example of this is the Cananea mining district in Sonora-Mexico, ranked among the 11 major mineral-producing countries in the world. Ore extraction during 150 years has removed entire hills in the area (Suppen et al. 2006). The continuous infiltration of acid leachate from the mines to the rivers changes the water quality, thus endangering human health and aquatic fauna (Gómez et al. 1986, 1990).

OnAugust 6" ${ }^{\text {th }}, 2014$ in "Buenavista del Cobre" mine (located in Cananea, Sonora) about 40,000 cubic meters $\left(\mathrm{m}^{3}\right)$ of acid solution were spilled from a dam into the Tinajas stream $(17.6 \mathrm{~km})$, the Bacanuchi River $(64 \mathrm{~km})$, and the Sonora River $(190 \mathrm{~km})$. The solution was highly acid and contained heavy metals. CONAGUA (National Water Commission) reported that the heavy metal concentrations for the acid solution were: Fe $\left(1080 \mathrm{mg} \mathrm{L}^{-1}\right), \mathrm{Al}\left(461 \mathrm{mg} \mathrm{L}^{-1}\right)$, $\mathrm{Cu}\left(114 \mathrm{mg} \mathrm{L}^{-1}\right), \mathrm{Mn}\left(98 \mathrm{mg} \mathrm{L}^{-1}\right), \mathrm{Zn}\left(51 \mathrm{mg} \mathrm{L}^{-1}\right)$, As (42.7 mg L-1), Ni (11 mg L-1), Cd (7.8 mg L-1), $\mathrm{Pb}$ (2.5 mg L-1), Cr (1.5 mg L-1) and pH 2.3 (Gutiérrez and Romero 2015).

The first report of ABC-Analitic (2014) indicated high concentrations of the metals: $\mathrm{Al}, \mathrm{Ba}$, $\mathrm{Cd}, \mathrm{Cu}, \mathrm{Cr}, \mathrm{Fe}, \mathrm{Mn}, \mathrm{Hg}, \mathrm{Ni}, \mathrm{Pb}, \mathrm{Zn}$ and metalloids: As, Sb in surface and groundwater samples collected in the basin of the Sonora River. Three months later, all the metal concentrations were measured below the maximum permissible limits set by the NOM-127 of drinking water regulations. The concentrations of $\mathrm{Fe}, \mathrm{Al}$, and $\mathrm{Mn}$ were high, but their concentration was considered to be natural, associated with the suspended colloidal fraction 
$\leq 0.45 \mu \mathrm{m}$ (Gutiérrez and Romero 2015). These results showed that the affected surface water was neutralized soon after the spill.

Díaz et al. (2015) showed chemical and micromorphological changes in the soils impacted by the acid solution associated with the 2014 event. In Bacanuchi River, the intact soils located on the terrace outside the spill-affected area present abundant carbonates, basic $\mathrm{pH}$ and low concentrations of the trace elements. In contrast, the affected soil was identified in the field by the visual color change, present high contents of metallic contaminants ( $\mathrm{Fe}, \mathrm{Cu}, \mathrm{As}, \mathrm{Pb}$ ) and has low $\mathrm{pH}$. The micromorphological studies showed changes in $\mathrm{Fe}$ oxi-hydroxides, precipitation of gypsum and an absence of carbonates that are common in the area. These changes were associated with the spill of the acid solution.

Both the dynamics of contaminant concentrations in the surface water and results from the soils affected by acid spill lead us to the hypothesis that 1) the soil of the Sonora River Basin played a major role in the neutralization of the acid mine spill and retention of contaminants dissolved in it; and 2) soil carbonates (both primary and secondary) serve as the main neutralizing agent in these soils and are consumed in the course of the soil-acid spill interaction.

The objective of this work is to study a soil profile with evidence of residual contamination produced by the 2014 spill and compare it with a column of soil in the area that was irrigated with the acid solution from the same mine. We performed micromorphological observations for the components and features formed or transformed in the course of interaction of the mine spill with the soil on site and in the laboratory conditions; and then micromorphometric quantification of these features. Micromorphological observations were coupled with the physical and chemical analyses: colorimetry, heavy metal content, $\mathrm{pH}$ and electrical conductivity (chemical properties) and mineralogical composition.

\section{Material and Methods}

\subsection{The study area}

The basin of the Sonora River covers an area of $30,913 \mathrm{~km}^{2}$, the study area is limited to the Bacanuchi River, which is part of the Sonora river basin. It is located in the north of the basin and has an extension of $64 \mathrm{~km}$. The geology of the region is formed by porphyry-rhyolitic intrusive rocks, granites and limestones of the upper middle Cambrian. To the northwest, the Sierra Azul is located, presenting andesites-ignimbrites rocks of the Paleogene and outcrops andesiticporphyries. The Sierra Pinito is located to the west of Bacanuchi river, with limestone-shales from the lower Cretaceous with conglomerates from the lower Jurassic. To the northeast, the Cerro Caracol is formed by altered ignimbrites of the Paleogene and andesites-sandstones of the upper Cretaceous (SGM 2008). During the Tertiary, magmatic activity produced the emplacement of magmatic-hydrothermal $\mathrm{Cu}-\mathrm{Mo}$ and related deposits. These deposits have been mined for several centuries, but activities intensified at the end of the 19th century (Bracamonte et al. 1997).

In the mining district of Cananea, the porphyry-related mineralization of Cu-Mo-W is more abundant (Valencia et al. 2006), and accounts for $7,140 \mathrm{Mt}$ of ore with $0.42 \% \mathrm{Cu}$ and $0.008 \%$ Mo (Singer et al. 2005). Additionally, $\mathrm{Zn}-\mathrm{Pb}-\mathrm{Cu}$ skarns and high-grade sulfide and iron oxide deposits are present (Meinert 1982).

The climate classification in the Bacanuchi area is characterized by a very dry to semi-dry climate (INEGI 1993). The warmest month is June, with an average temperatura of $36.5^{\circ} \mathrm{C}$ and the coldest in December with an average of $0.4^{\circ} \mathrm{C}$. The annual rainfall is $628 \mathrm{~mm}$ (CONAGUA 2018). Predominant soils in the area are Regosols and Leptosols, and to a lesser extent Phaeozems, Calcisols, and Fluvisols (Krasilnikov et al. 2013).

\subsection{Fieldwork and sampling}

The profile denominated BZII (longitude $\mathrm{X}=$ 0570372 , latitude $Y=3391868$ ) is located $36 \mathrm{~km}$ 
away from the Buenavista del Cobre mine, on the first fluvial terrace of the Bacanuchi River at 1,082 m.a.s.l. There is a color change in one of the lower horizons $(3 \mathrm{C})$ of the soil that is attributed to the impact of the acid solution. The profile composed of six horizons (AC-2Ag-2C-3A-3Calluvial sediment) was described in the field and the samples were collected from each horizon for the chemical, mineralogical and colorimetric analysis characterization in laboratory. Two (2C and $3 \mathrm{C}$ horizons) undisturbed soil samples were taken for micromorphological and morphometric analysis.

For the laboratory experiment two uncontaminated soil columns of $25 \mathrm{~cm}$ length were sampled at the surface of a terrace in the Bacanuchi
River located $41 \mathrm{~km}$ from the mine (longitude $X=5715307$, latitude $Y=337955.7$ ), the altitude is 1083 m.a.s.l. The columns were placed on a porous CPVC base, between the base and the bottom of the columns a nitrocellulose filter with a pore diameter of $0.5 \mu \mathrm{m}$ was placed, and then a layer of fine, chemically pure sand. The filter prevented the loss of soil at the base of the column. It is important to note that the columns allowed the original structure of the soil to be maintained. One of the columns was used in laboratory for the acid solution treatment, the other column was used for the chemical and mineralogical characterizations. The acid solution was sampled in the dam called Tinajas 1 in the Buenavista del Cobre mine. Geographical position of the sampling sites is shown in Figure 1.

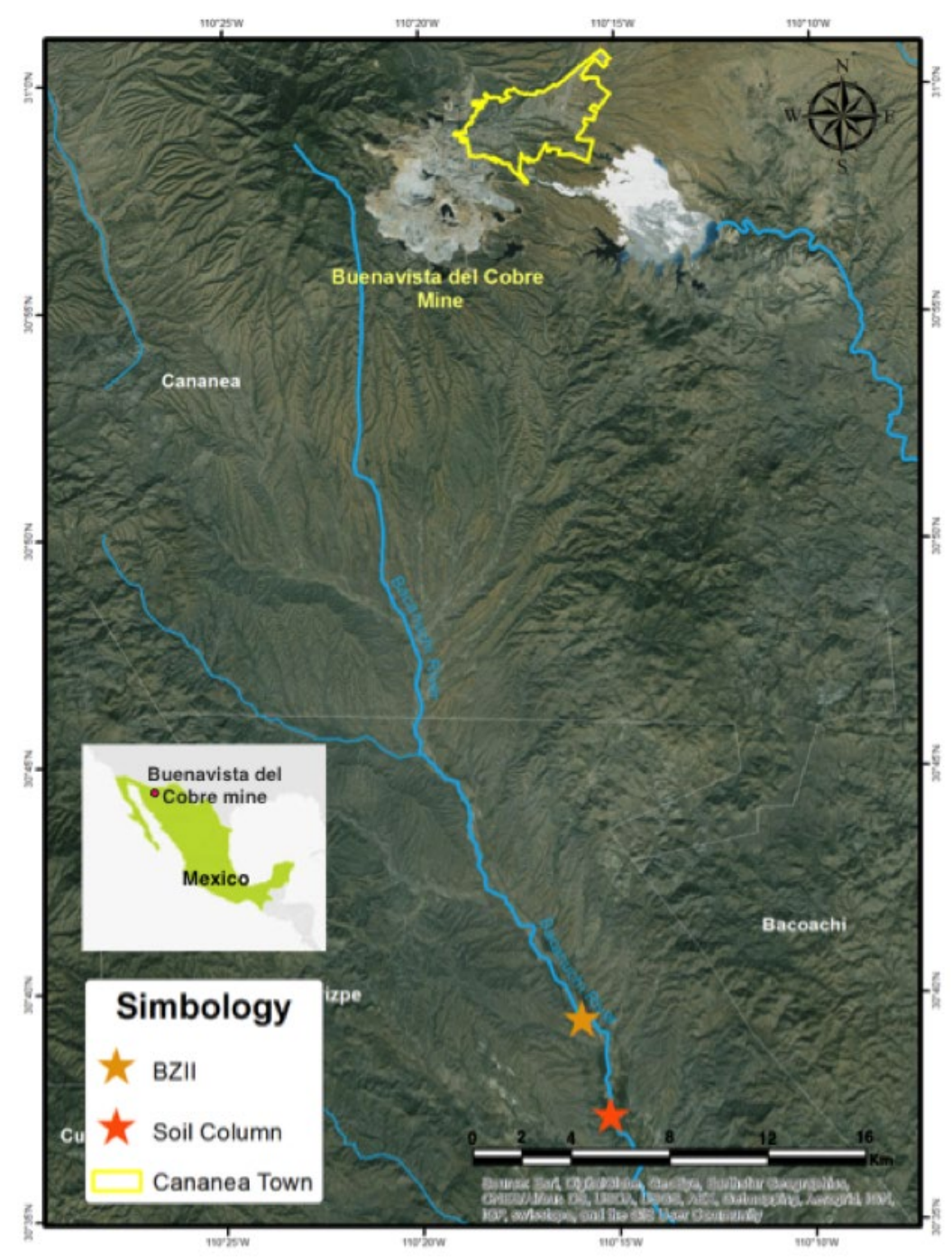

Figure 1. Location area of the "Buenavista del Cobre" mine, profile BZII and uncontaminated soil columns. 
2.3. Profile BZII: geochemical, mineralogical characterization and chemical analysis

The samples were dried at room temperature and sieved to separate the coarse fraction (> $2 \mathrm{~mm}$ ); subsequently, the $<2 \mathrm{~mm}$ fraction was prepared for laboratory analyses.

The $\mathrm{pH}$ and the EC were determined in a 1:5 suspension of soil with Milli-Q deionized water, which was shaken for $1 \mathrm{~h}, \mathrm{pH}$ was measured using a calibrated $\mathrm{pH}$-meter Denver Instrument Ultrabasic and EC was determined using an Oakton 700 equipment.

The concentrations of major and trace elements were determined by X-ray fluorescence. ARigaku Primus II ZSX with pressed sample pellets was used for major ion determination, and a portable Thermo Scientific Nitton FXL 959 model was used for trace element determination.

The mineralogy was assessed by X-ray diffraction (XRD) using an Empyrean diffractometer with $\mathrm{Cu}$ $X$-ray radiation in the non-oriented specimens of the bulk sample. Before the analysis, the samples were grounded and homogenized with an agate mortar.
2.4. Chemicals and mineralogical analysis of the untreated and treated columns

For the physical determinations the Manual of Analytical Procedures was used (Flores and Alcalá 2010). The texture was determined by the Bouyoucos hydrometer method. Determination of the apparent density and the real density were made by using the test tube method and the pycnometer method, respectively. Finally, the porosity was obtained using the following equation:

$$
\text { Porosity }(\%)=(1-(d a / d r) * 100(1)
$$

where da, apparent density $\left(\mathrm{g} / \mathrm{cm}^{3}\right)$; dr, real density $\left(\mathrm{g} / \mathrm{cm}^{3}\right)$.

The concentrations of major elements and trace elements in the samples taken at 3 different depths in each column were performed by $\mathrm{X}$ ray Fluorescence, for which Thermo Scientific Nitton FXL 959 portable equipment was used. Before the analysis, $200 \mathrm{~g}$ of homogenized sample, finely ground (mesh 10) and placed inside plastic bags were used for these analyses. The X-ray diffraction analysis was developed in an Empyrean diffractometer equipped with Ni filter, fine focus copper tube and PIXcel3D detector. The samples were ground and homogenized by an agate mortar.

Table 1. Volume and area of the soil column

\begin{tabular}{cccc}
$\begin{array}{c}\text { Height } \\
(\mathbf{c m})\end{array}$ & $\begin{array}{c}\text { Diameter } \\
(\mathbf{c m})\end{array}$ & $\begin{array}{c}\text { Area of the base } \\
\left(\mathbf{c m}^{2}\right)\end{array}$ & $\begin{array}{c}\text { Volume } \\
\left(\mathbf{c m}^{3}\right)\end{array}$ \\
\hline 20.5 & 14.5 & 165.1 & 2,200 \\
\hline
\end{tabular}

2.5. Simulation of the uncontaminated soil column with the acid solution in laboratory

For the simulation of the interaction of the acidic solution with the soil, a column containing the unchanged soil with the following dimensions was used: $21 \mathrm{~cm}$ in height with $14.5 \mathrm{~cm}$ in diameter. The acid solution was applied in a single episode using the same amount of volume as the pore space in the column, 2,200 $\mathrm{ml}$, in order to use the necessary amount and avoid the problem that the entire solid phase will not interact completely. The mode of application was to use a head on the top of the column that was constantly passing the solution until the measured amount was exhausted.

After the simulation experiment the column was cut longitudinally to obtain $300 \mathrm{~g}$ of soil in the first 4 $\mathrm{cm}$ of the column for the chemical, mineralogical and colorimetric characterizations. On the other hand, unaltered samples of the soil were also obtained to elaborate the thin sections for the micromorphology and morphometry. Finally, for the characterization of major and trace elements the acid solution was filtered with $0.45 \mu \mathrm{m}$ nitrocellulose paper, using an ICP_OES EImer model 8300DV. 


\subsection{Colorimetric analysis}

A colorimetric analysis was performed to compare and quantify the color change between the impacted horizon and non-impacted horizons in BZII profile; in the same way, identify the color change in the soil before and after the simulations with the column.

In the $15 \mathrm{~g}$ samples previously dried, the reflectance spectra were analyzed with the colorimeter spectrophotometrer SPH 860, previously calibrated with the white color. Two readings were taken for each soil sample. The results were calculated based on the CIE-LAB (Commission Internationale de l'Éclairage) system recommended to numerically evaluate the colors, the parameters $L^{*}, a^{*}, b^{*}$ are used where $L^{*}\left(0-100\right.$ lightness scale), $a^{*}$ (red $+a^{*}$ green $-a^{*}$ scale), and $b^{*}$ (yellow $+b^{*}$ blue- $b$ * scale). The differences between the samples were quantified using the $\mathrm{CIE}$ equation: $\Delta \mathrm{E}{ }^{*}=$ $\left[\Delta \mathrm{L}^{* 2}+\Delta \mathrm{a}^{* 2}+\Delta \mathrm{b}^{* 2}\right] 1 / 2$. For this equation were first compared the column treated with the acid solution with the non-experimental column, second the following horizons: $2 \mathrm{Ag}-2 \mathrm{C}, 2 \mathrm{C}-3 \mathrm{C}$, $2 \mathrm{C}$-alluvial sediment, $3 \mathrm{~A}-2 \mathrm{C}$, column treated-3C and $2 \mathrm{C}$-column treated with the acid solution.

\subsection{Micromorphological and morphometric analysis}

Undisturbed samples taken from two horizons ( $2 \mathrm{C}$ and $3 \mathrm{C}$ ) in the profile BZII and the columns before and after the irrigation were air dried, and subsequently impregnated with polyester resin. After their hardening, they were cut to a thickness of 30 microns to produce thin sections. These sections were studied using a petrographic microscope Olympus BX51.

The morphometric analysis was done using microphotographs obtained with Cool Snap Pro Color camera observed under the same petrographic microscope 4X objective (area $1.94 \mathrm{~mm}^{2}$ ). Then, the images were calibrated and analyzed with Image Pro Plus version 7.0 program. The following areas were separated and quantified in the impacted samples (horizon $2 \mathrm{C}$ and the column before irrigating) and the impacted samples (horizon $3 \mathrm{C}$ and the column after irrigation): 1) those enriched with fine material with reddish color due to ferruginous pigment and 2) those consisting of other components: coarse minerals, fine materials without ferruginous pigmentation, organic fragments and pores. Three different points were measured in each thin section. The objective was to know if there is an increase of the areas rich in $\mathrm{Fe}$ in samples impacted by the acid solution.

\section{Results and Discussion}

\subsection{BZII profile description}

The BZII profile is located in the first alluvial terrace of the Bacanuchi river and presents the following horizons AC $(0-30 \mathrm{~cm}), 2 \mathrm{Ag}(30-80 \mathrm{~cm})$, 2C (80-140 cm), 3A (140-200 cm), 3C (200-240 $\mathrm{cm}$ ) alluvial sediment $(>240 \mathrm{~cm})$. All the horizons presented weak development of the pedogenetic properties with evidence of a constant fluvial deposition; only the $2 \mathrm{Ag}$ horizon has subangular structure and is enriched in organic matter. The color was light brown and the profile reacts with $10 \% \mathrm{HCl}$, pointing to the presence of calcium carbonates. The contents of fractions of sand, silt and clay are represented in the Figure 2. The textural classes of the horizons are: $\mathrm{AC}$ sandy clay loam, 2Ag silty clay loam, 2C sandy clay loam, 3A silty clay, $3 \mathrm{C}$ sandy loam and alluvial sediment silt. This profile was classified as Calcic Fluvisol (IUSS Working Group WRB 2015).

The color changes to yellowish orange at a depth of 2-2.40 $\mathrm{m}$ corresponding to the horizon 3C. Field observations have shown that the orange pigmentation is a result of the contact of soils and sediments with the acid solution (the spill from the Buenavista del Cobre mine). The acid solution did not reach the horizons located above $3 \mathrm{C}$, and so these were not affected.

\subsection{Chemical and mineralogical analysis}

Profile BZII: the values of electrical conductivity in all horizons are below $289.3 \mu \mathrm{S} / \mathrm{cm}$; except in the $3 \mathrm{C}$ horizon with much higher value of 
$2,160 \mu \mathrm{S} / \mathrm{cm}$, in this horizon a change in color is observed in the field (yellowish orange). The $\mathrm{pH}$ of the profile is high, varying between 7.68.1 , but in the horizon $3 \mathrm{C}$ it decreases to 7 . The $\mathrm{X}$-ray fluorescence results show an increase of concentrations of $\mathrm{Fe}(4.61 \%)$, As $\left(37.7 \mathrm{mg} \mathrm{kg}^{-1}\right)$, $\mathrm{Cu}\left(815.6 \mathrm{mg} \mathrm{kg}^{-1}\right)$ and $\mathrm{Pb}\left(57.2 \mathrm{mg} \mathrm{kg}^{-1}\right)$ in the $3 \mathrm{C}$ horizon with respect to the other horizons of the BZII profile (Table 2). The X-ray diffraction in the horizon $2 \mathrm{C}$ identifies quartz, plagioclase of intermediate composition, and small quantities of calcite. In the $3 \mathrm{C}$ horizon the mineralogical composition changes, although quartz and plagioclase of intermediate composition are present as in 3C, the new components - gypsum and jarosite are identified whereas the calcite was absent (Table 3).

Table 2. Particle size distribution, $\mathrm{pH}$, electrical conductivity $(\mathrm{EC})$ and concentrations of $\mathrm{Fe}, \mathrm{As}, \mathrm{Cu}, \mathrm{Zn}$ and $\mathrm{Pb}$ elements in the BZII Profile

\begin{tabular}{ccccccccccccc} 
Horizon & Depth & Sand & Silt & Clay & pH & EC & Fe & Cu & As & Pb & Zn \\
& $\mathrm{cm}$ & & $\%$ & & & $\mu S / c m$ & $\%$ & & \multicolumn{2}{c}{$\mathrm{mg} \mathrm{kg}^{-1}$} \\
\hline $\mathrm{AC}$ & $0-30$ & 63.13 & 15.81 & 21.07 & 7.70 & 161.90 & 3.24 & 70.51 & 25.12 & 48.03 & 93.27 \\
\hline $2 \mathrm{Ag}$ & $30-80$ & 11.30 & 52.17 & 36.53 & 7.60 & 178.50 & 2.85 & 48.65 & 22.52 & 46.39 & 113.47 \\
\hline $2 \mathrm{C}$ & $80-140$ & 55.00 & 21.53 & 23.47 & 7.90 & 158.20 & 2.99 & 49.46 & 23.54 & 32.58 & 80.50 \\
\hline $3 \mathrm{~A}$ & $140-200$ & 5.74 & 49.19 & 45.07 & 8.00 & 289.30 & 2.86 & 57.19 & 26.44 & 42.52 & 125.73 \\
\hline $3 \mathrm{C}$ & $200-240$ & 69.10 & 12.50 & 18.40 & 7.00 & 2160.00 & 4.61 & 815.67 & 37.70 & 57.23 & 259.54 \\
\hline $\begin{array}{c}\text { Alluvial } \\
\text { sediment }\end{array}$ & $>240$ & 92.35 & 2.32 & 5.33 & 8.10 & 79.60 & 3.65 & 104.62 & 26.15 & 43.70 & 92.30 \\
\hline
\end{tabular}

In the column samples the results of X-ray fluorescence of the samples at 3 depths $(0,2$ and $4 \mathrm{~cm}$ ) reflects changes in the concentration of $\mathrm{Pb}, \mathrm{Cu}, \mathrm{Mn}$ and Fe between the column before and after the infiltration. A slight increase of the $\mathrm{Pb}$ concentration is observed in the depths of 2 and $4 \mathrm{~cm}$; values before infiltration were 34 and $43 \mathrm{mg} \mathrm{kg}^{-1}$, in the treated samples they reach 39 and $49 \mathrm{mg} \mathrm{kg}^{-1}$ (Figure 2A).

An increase of the total concentration of $\mathrm{Cu}$ was observed at all the depths analyzed in the experimental column. The initial values were from 98.2 to $119.9 \mathrm{mg} \mathrm{kg}^{-1}$; after the infiltration they increased to 811.6-886.8 $\mathrm{mg} \mathrm{kg}^{-1}$. The concentration of $\mathrm{Mn}$ increased similarly. Initially, the range was from 665.2 to $835.8 \mathrm{mg} \mathrm{kg}^{-1}$, after interaction with the acid solution the values were obtained from 884.7 to $1,098.8 \mathrm{mg} \mathrm{kg}^{-1}$ (Figure 2B).

The greatest increase concerned $\mathrm{Fe}$, the element with highest concentration in the acid solution. The initial concentrations of the column are from $33,783.1$ to $37,435.2 \mathrm{mg} \mathrm{kg}^{-1}$; finally, after the treatment the values increased from $44,382.3$ to $45,982.1 \mathrm{mg} \mathrm{kg}^{-1}$ (Figure 2C).
Only for As the tendency to increase is not observed, the concentration remained constant, values range from 21.7 to $26 \mathrm{mg} \mathrm{kg}^{-1}$.

The analysis of X-ray diffraction in the column not treated with the acid solution identified the following minerals: quartz, plagioclase of the intermediate composition, calcite and phyllosilicates such as vermiculite and illite. A mineralogical change took place in the soil column treated with the acid solution, evidenced by the emergence of new minerals: gypsum, ferrihydrite, schwertmannite and jarosite, although in small quantities according to the semi-quantitative analysis. Another important result is the absence of calcite (Table 3 ).

The chemical characterization of the acid solution determined the presence of the following elements: $\mathrm{Fe}, \mathrm{Al}, \mathrm{Cu}, \mathrm{Mn}, \mathrm{As}, \mathrm{Pb}, \mathrm{Cd}, \mathrm{Zn}$. The electrical conductivity was $17260 \mu \mathrm{S} / \mathrm{cm}$ and the $\mathrm{pH}$ was 2.43. Table 4 shows the concentrations of the metals. 


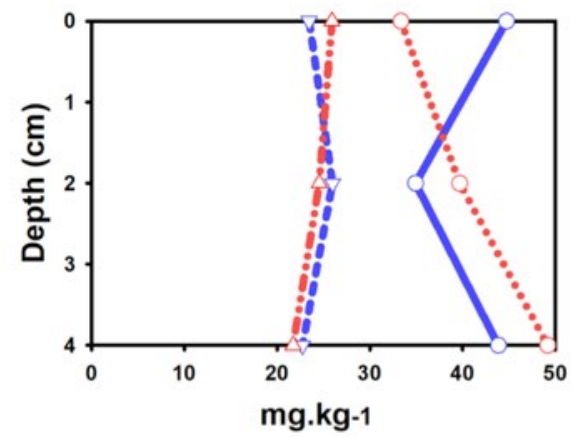

A

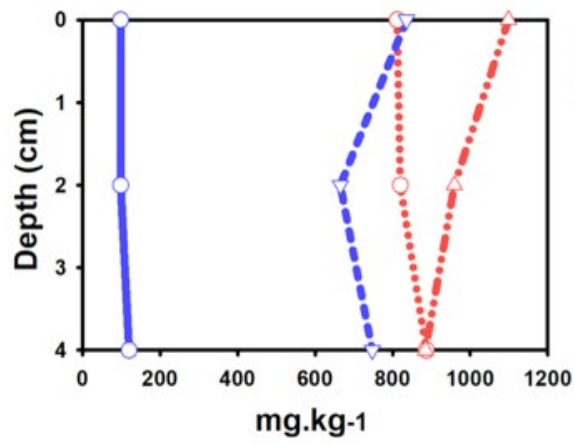

B
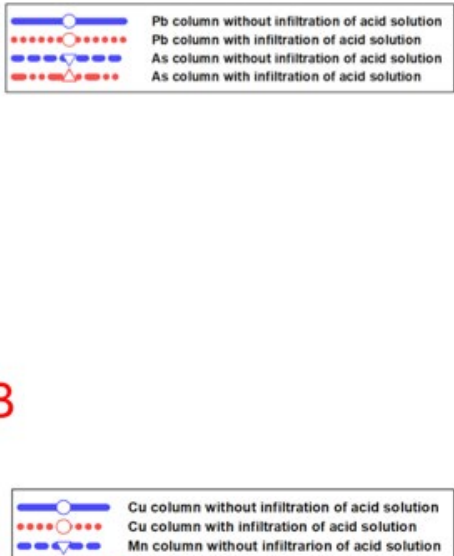

Mn column with infiltration of acid solution

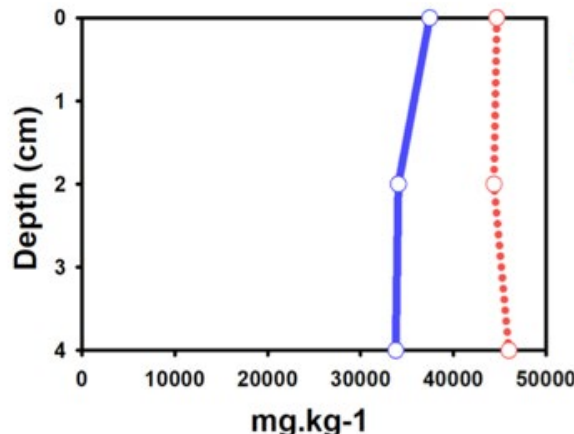

C - Fe column without infiltration of acid solution
- - Fe column with infiltration of acid solution

Figure 2. Total concentration of the $\mathrm{As}, \mathrm{Pb}, \mathrm{Cu}, \mathrm{Mn}$ and $\mathrm{Fe}$ in the column with and without infiltration of acid solution in the laboratory. A-lead $(\mathrm{Pb})$ and arsenic $(\mathrm{As})$. B- copper $(\mathrm{Cu})$ and Manganese. C-iron (Fe).

\subsection{Colorimetry}

In order to observe the color changes in the soil column treated and not treated with the acid solution and the profile BZII, a colorimetric analysis was performed; the results were presented in Figure 3.

In the profile BZII most intense change occurs in the horizon $3 \mathrm{C}$ whose value of a parameter (red color) is 8 , whereas in the others horizons (AC, 2A, 2C, 3A, alluvial sediment) were below 5.01. Similarly, an increase in yellow coloration (parameter $b$ ) is observed in $3 C$, with a value of 18 , the other horizons of the profile BZII have values below 11. This analysis allows us to observe the changes in the samples affected by the acid solution, which we associate with the precipitation of fine Fe oxi-hydroxides (like ferrihydrate).

In the same way, a strong change in the yellow and red colors (parameters $b$ and a respectively) in the column treated with the acid solution was observed in comparison to the column without treatment. In the yellow color an increase of 17.2 to 18.5 and in the color red increase of 4.9 to 6.1 .

The results of the equation $\Delta \mathrm{E}^{*}$ in Table 5 showed an important color differences, the columns treated and non-treated with acid solution 
Table 3. Mineralogy of the soil columns and the horizons $2 \mathrm{C}$ and $3 \mathrm{C}$

\begin{tabular}{|c|c|c|c|c|}
\hline $\begin{array}{l}\text { Minerals identified } \\
\% \text { (semi-quantitative) }\end{array}$ & $\begin{array}{l}\text { Column without } \\
\text { acid solution } \\
\text { treatment }\end{array}$ & $\begin{array}{c}\text { Column with acid } \\
\text { solution } \\
\text { treatment }\end{array}$ & $\begin{array}{l}\text { BZII Horizon } \\
\text { 2C }\end{array}$ & $\begin{array}{l}\text { BZII } \\
\text { Horizon } \\
3 C\end{array}$ \\
\hline 1. Quartz: $\mathrm{SiO}_{2}$ & 47 & 41 & 21 & 33 \\
\hline $\begin{array}{l}\text { 2. Plagioclase intermediate composition: } \\
\left(\mathrm{NaAlSi}_{3} \mathrm{O}_{8} \text { to } \mathrm{CaAl}_{2} \mathrm{Si}_{2} \mathrm{O}_{8}\right)\end{array}$ & 30 & 27 & 27 & 19 \\
\hline 3. Calcite: $\mathrm{CaCO}_{3}$ & 4 & 0 & 1 & 0 \\
\hline 4. Phyllosilicates $\approx 14 \AA \mathrm{pbb}$ : Vermiculite & 5 & 3 & 0 & 10 \\
\hline 5. Phyllosilicates $\approx 10 \AA \mathrm{pbb}$ : Illite & 14 & 9 & 0 & 0 \\
\hline 6. Gypsum: $\left(\mathrm{CaSO}_{4}\right)_{2} \cdot 2 \mathrm{H}_{2} \mathrm{O}$ & 0 & 14 & 0 & 4 \\
\hline 7. Ferrihydrite: $\left(\mathrm{Fe}^{3+}\right) 4-5(\mathrm{OH}, \mathrm{O})_{12}$ & 0 & 3 & 0 & 0 \\
\hline $\begin{array}{l}\text { 8. Schwertmannite: } \\
\mathrm{Fe}^{3+}{ }_{16} \mathrm{O}_{16}(\mathrm{OH})_{12}\left(\mathrm{SO}_{4}\right)_{2}\end{array}$ & 0 & 2 & 0 & 0 \\
\hline 9. Jarosite: $\mathrm{KFe}_{3}\left({ }^{3+}\right)\left(\mathrm{SO}_{4}\right)^{2}(\mathrm{OH})_{6}$ & 0 & 1 & 0 & 2 \\
\hline 10. Muscovite: $\mathrm{KAL}_{2}\left(\mathrm{AlSi}_{3} \mathrm{O}_{10}\right)(\mathrm{OH})_{2}$ & 0 & 0 & 21 & 23 \\
\hline $\begin{array}{l}\text { 11. Phyllosilicates } \approx 14 \AA \mathrm{pbb} \text { : } \\
\text { Montmorillonite }\end{array}$ & 0 & 0 & 17 & 0 \\
\hline 12. Sanidine: $(\mathrm{KNa})(\mathrm{SiAl})_{4} \mathrm{O}_{9}$ & 0 & 0 & 13 & 9 \\
\hline
\end{tabular}

Table 4. Composition of the acid solution

\begin{tabular}{cc} 
Element & $\begin{array}{c}\text { Concentration } \\
\text { mg L}^{-1}\end{array}$ \\
\hline $\mathrm{Al}$ & 4264.84 \\
\hline $\mathrm{As}$ & 1.08 \\
\hline $\mathrm{Cd}$ & 4.05 \\
\hline $\mathrm{Cu}$ & 787.12 \\
\hline $\mathrm{Fe}$ & 3430.09 \\
\hline $\mathrm{Mn}$ & 643.92 \\
\hline $\mathrm{Pb}$ & 0.18 \\
\hline $\mathrm{Zn}$ & 377.28 \\
\hline
\end{tabular}

present the highest value of $\Delta \mathrm{E}^{*}=10.125$. In the same way, the horizons $2 \mathrm{C}$ and $3 \mathrm{C}$ have high $\Delta E^{*}=8.177$. On the other hand, the samples that show no evidence of interaction with the acid solution show rather low values of this coefficient for example, for the $2 \mathrm{C}$ horizon and alluvial sediment $\Delta \mathrm{E}^{*}=1.364$.

\subsection{Micromorphological observation}

In the profile BZIl thin sections from two horizons: $2 \mathrm{C}$ and $3 \mathrm{C}$ were analyzed to identify the most conspicuous microscopic differences, evidences of the naturals conditions (2C) and the interaction with the acid solution (3C).
The horizon 2C presents groundmass made up predominantly of sand particles with a weak structure, and coarse monic c/f related distribution (Figure 4A). Microlaminations with particle size ranging from fine sand to silt were identified in the upper part of the horizon (Figure 4D). Mineralogical composition of sand is dominated by quartz and plagioclases, minor quantities of micas, epidote and hornblende are also present. Only biotite showed very weak signs of weathering, other minerals look completely fresh (Figure 4C). The identified carbonates are mainly primary sand-size grains of calcite probably derived from limestones (Figure 4F). Neoformed pedogenic carbonates 


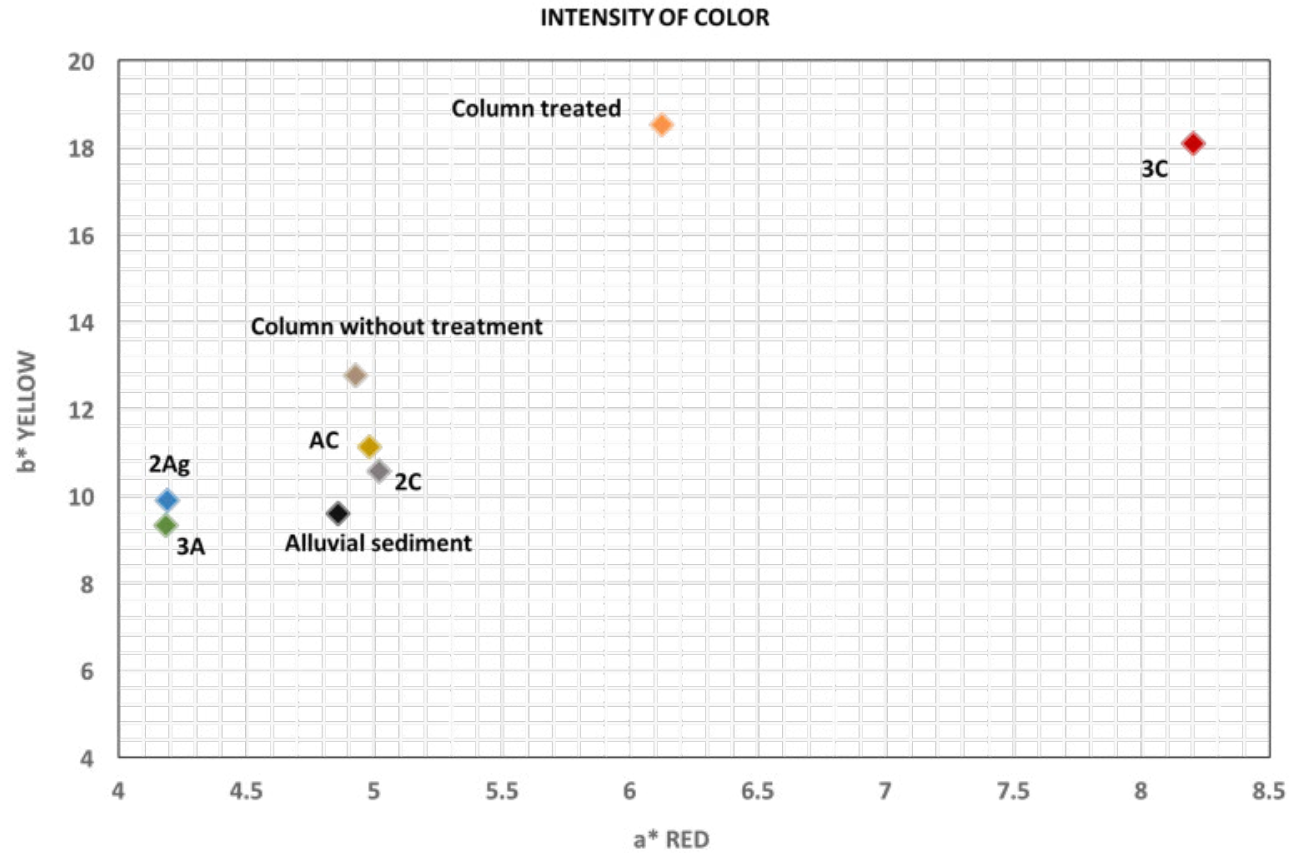

Figure 3. Colorimetry of all soil samples.

Table 5. Delta E Results

\begin{tabular}{lcccc}
\multicolumn{1}{c}{ Samples } & $\boldsymbol{\Delta} \mathbf{E}^{*}$ & $\boldsymbol{\Delta} \mathbf{L}^{*}$ & $\boldsymbol{\Delta} \mathbf{a}^{*}$ & $\boldsymbol{\Delta} \mathbf{b}^{*}$ \\
Column without infiltration-with infiltra & 10.125 & 8.254 & 1.197 & 5.750 \\
\hline Column with infiltration-3C & 2.328 & -0.441 & -2.077 & 0.955 \\
\hline 2C-column with infiltration & 8.056 & 0.688 & -1.106 & -7.951 \\
\hline 2C-3C & 8.177 & 0.247 & -3.183 & -7.529 \\
\hline 2C-alluvial sediment & 1.364 & -0.942 & 0.160 & 0.973 \\
\hline 2Ag-2C & 1.593 & -1.190 & 0.828 & 0.662 \\
\hline 2C-3A & 1.565 & -0.477 & 0.835 & 1.235 \\
\hline
\end{tabular}

are presented with micrite and microsparite that fills the packing voids among sand particles and locally cements the groundmass (Figures 4B, 4E). Calcified cells are observed in some fragments of roots.

Horizon $3 \mathrm{C}$, similar to the $2 \mathrm{C}$ horizon, presents weak structure, and a domination of sand size particles within the groundmass. The specific feature of this horizon are ferruginous fine material between sand grains (Figures 5A, 5B) and the small elongated gypsum crystals showing radial intergrowth are observed together with the concentrations of fine material (Figures 5C, 5D), whereas carbonates were absent.
In the soil column before the simulation experiment we also observed sandy composition of the groundmass, coarse monic with relative distribution and weak pedogenic structure (Figure 6B). Reddish ferruginous fine material is observed only inside some mineral sand grains where it could be a weathering product. The predominant sand minerals are quartz, phyllosilicates, opaque minerals and primary carbonates (Figure 6A).

The thin sections from soil column treated with the acid solution concentration of the reddish fine material with ferruginous pigment forming coatings on and bridges between the sand grains 

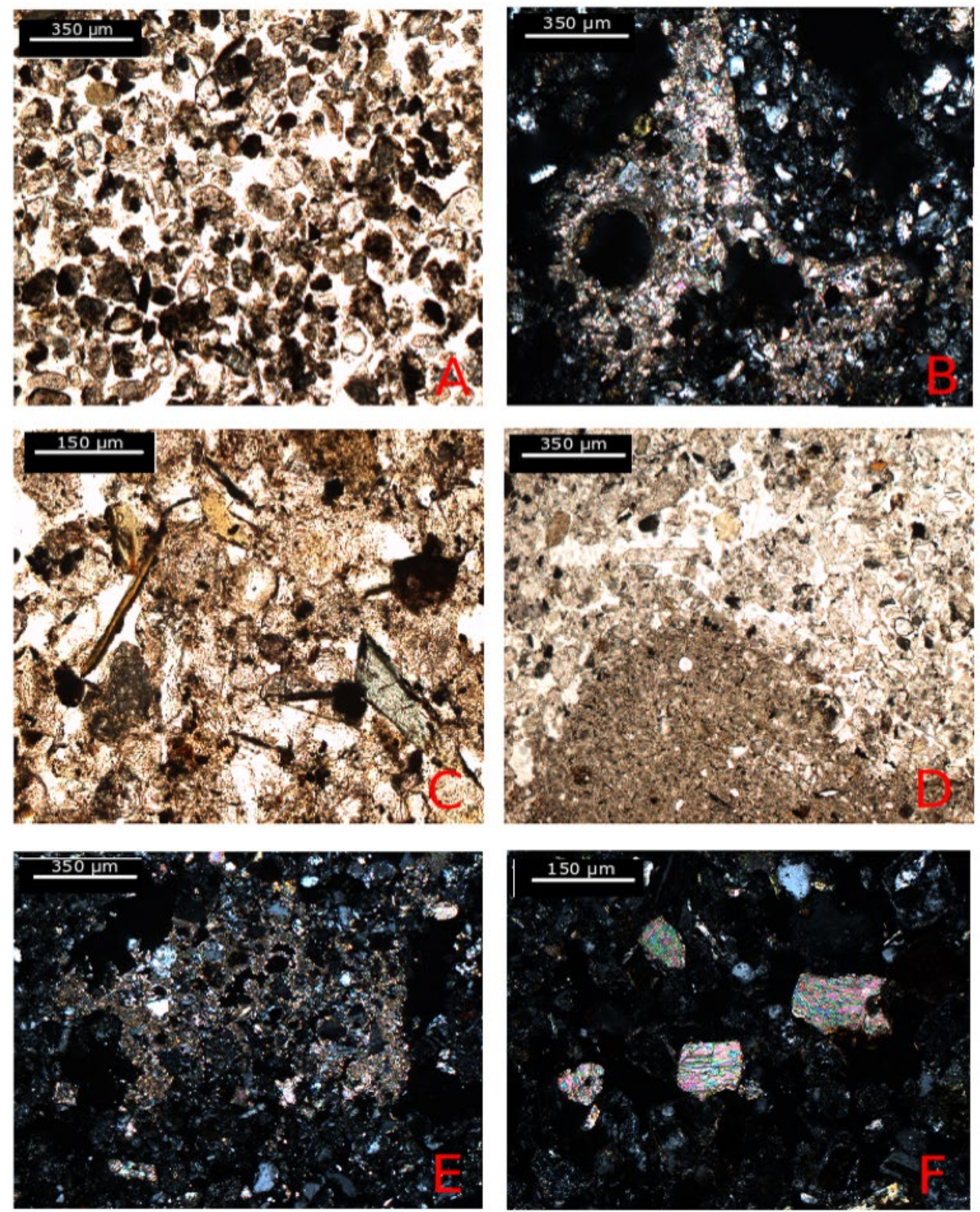

Figure 4. Micro-photographs of the $2 \mathrm{C}$ horizon. A. Sandy groundmass, coarse monic c/f related distribution, PPL; B. Neoformed microsparite locally cementing the soil material, N+; C. Slightly weathered biotite (left), fresh amphibole (right), PPL; D. Microlamination: sandy layer above, silty layer below, PPL; E. Neoformed micrite among sand grains, N+; F. Primary sand-size calcite. Note: $\mathrm{N}+$ cross polarizers.

(Figure 6C), not found in the non-treated soil. Near to the concentrations of ferruginous fine material we also identified neoformed gypsum with radial intergrowth (Figure 6D), whereas carbonates are absent. Another property is an apparent decrease of total porosity in the sample affected by the acid solution compared to the original sample.

\subsection{Morphometric analysis}

The micromorphological observations have shown that one of the most notorious results of soil transformation due to acid solution impact is the increase of the reddish fine material enriched with ferruginous pigment. The micromorphometric analysis was carried out to quantify this component and show numerical differences 

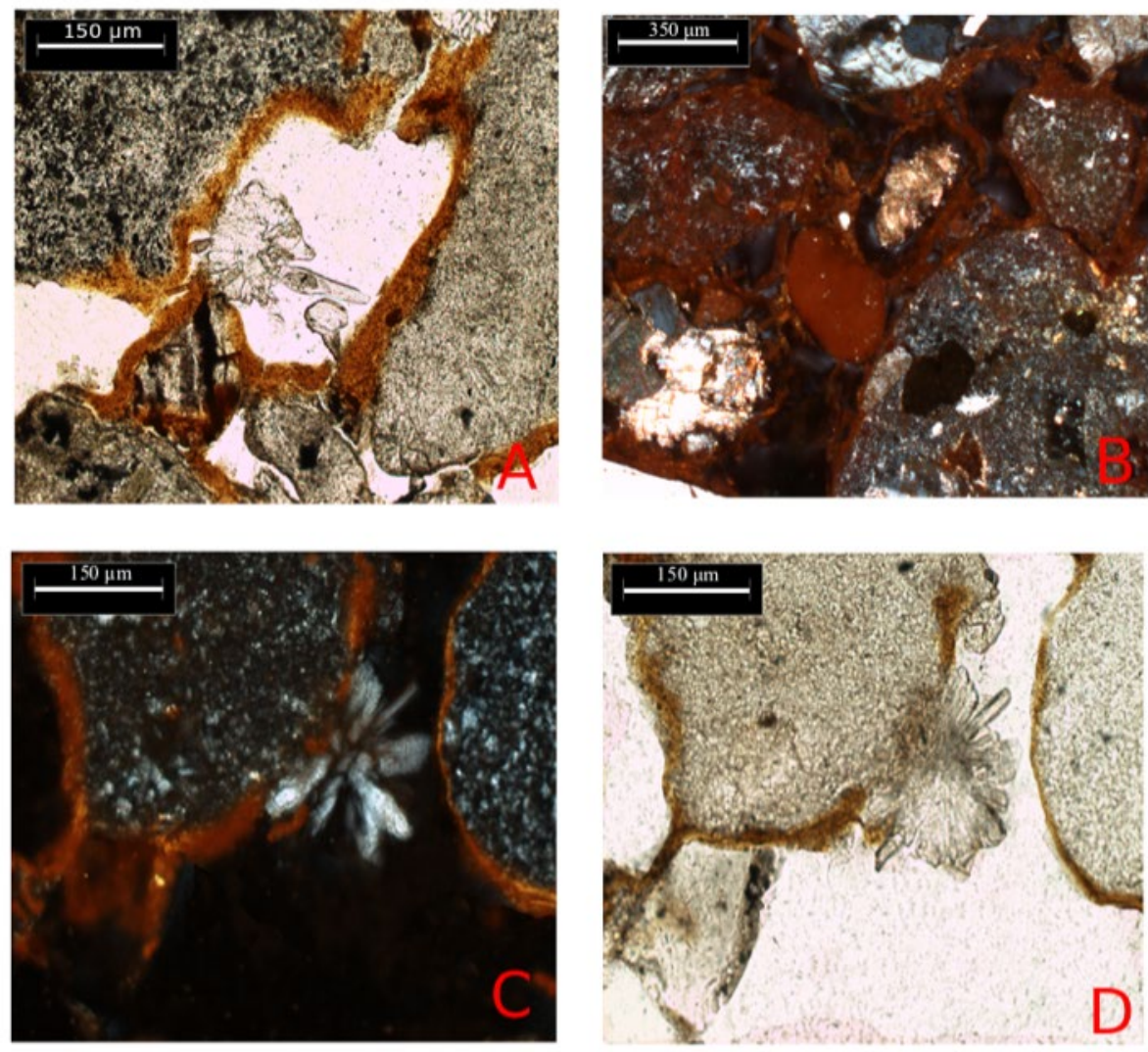

Figure 5. Micro-photographs of the horizon 3C. A. Coatings of ferruginous fine material on the plagioclase grain, $\mathrm{N}+$; $\mathrm{B}$. Compact rounded microaggregate of fine material $\mathrm{N}+; \mathrm{C}$, Neoformed gypsum associated with the ferruginous fine material, $\mathrm{N}+; \mathrm{D}, \mathrm{Bridges}$ of ferruginous fine material between sand grains, $\mathrm{N}+$. Note: $\mathrm{N}+$ cross polarizers.

of its content in the affected and intact soils. In the images analyzed with the Image Pro Plus 7.0 program, three principal areas were separated: in red ferruginous fine material, in blue pores, opaque components (organic and inorganic) and in green other coarse and fine minerals. It is possible to observe the increase of the red color area between the unaffected (2C) and affected by the acid solution (3C) samples (Figures 7A, 7B). In the same way, such increase is observed between the non-experimental column (Figure 7D) and the experimental column (Figure 7C).

The morphometric results are shown in Table 6. The porosity, opaque minerals and other minerals are grouped as "other components" in order to better identify the changes of the reddish fine material contents. The BZII profile shows an increase of the ferruginous fine material between horizon $2 \mathrm{C}$ with an average $=36.2 \%$ and $3 \mathrm{C}$ horizon with an average $=49.8 \%$. On the other hand, in the column before the simulation experiment the result showed an average $=29.03 \%$ of fine material rich in iron, increasing to $55.6 \%$ with the interaction the acid solution.

The other components that are not enriched with the ferruginous pigment decrease from $63.4 \%$ in the $2 \mathrm{C}$ horizon to an average of $50.1 \%$ in the $3 \mathrm{C}$ horizon. The sample before irrigation with the acid solution had an average of non-ferruginous components of $70.9 \%$, whereas after irrigation it changed to just $44.2 \%$. 

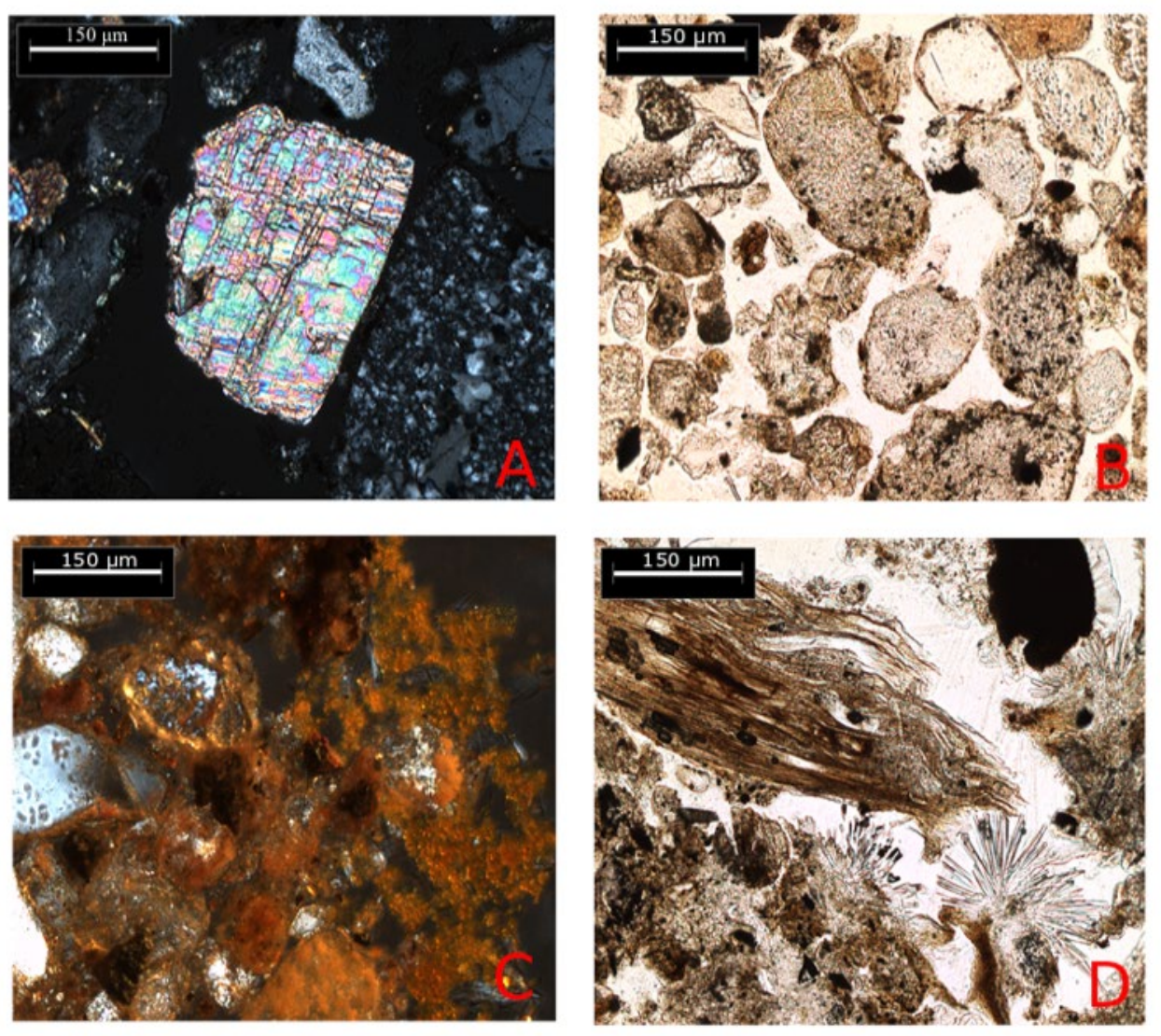

Figure 6. Microphotographs of the thin sections of the column without $(A, B)$ and with $(C, D)$ acid treatment. A-Primary carbonate grain, $\mathrm{N}+$; B- Sandy groundmass with coarse monic c/f related distribution, PPL; C- Coatings of ferruginous fine material over sand grains, $\mathrm{N}+; \mathrm{D}$, Neoformed gypsum crystals, PPL. Note: $\mathrm{N}+$ cross polarizers.

\section{Discussion}

The two cases, profile BZII (horizon 3C) and the experimental column showed evidence of the interaction with the acid solution. Only in the case of BZII it is directly related to the mining accident of 2014.

Micromorphological observations have shown that soil matrix of both objects not affected by acid solution is characterized by poor development of pedogenic features. Their microstructure is very weak, organic materials are scare and presented predominantly by undecomposed plant tissue fragments. Their low weathering status is justified by the presence of easily weatherable minerals like glauconite and amphiboles in the sand fraction (where they look quite fresh) and very low quantities of the fine secondary mineral components like clay and fine iron oxides, so that the $\mathrm{c} / \mathrm{f}$ related distribution is coarse monic in both cases. At the same time, the micro laminations are indicative of the fluvial environments of the first terrace in which the BZII profile and the soil column are located; this confirms definition of the soils as Fluvisols.

Carbonate component of the studied soils as far as it is supposed to be the most reactive component in the course of interaction (natural or experimental) with the acid solution. Primary sand-size calcite and dolomite are common within the coarse material, being mixed with the silicate grains derived from local rocks. We also observed micritic and microsparitic pedogenic carbonates (secondary), some of them associated with the plant residues. Taking into account the smaller crystal size of the secondary carbonates and their location 

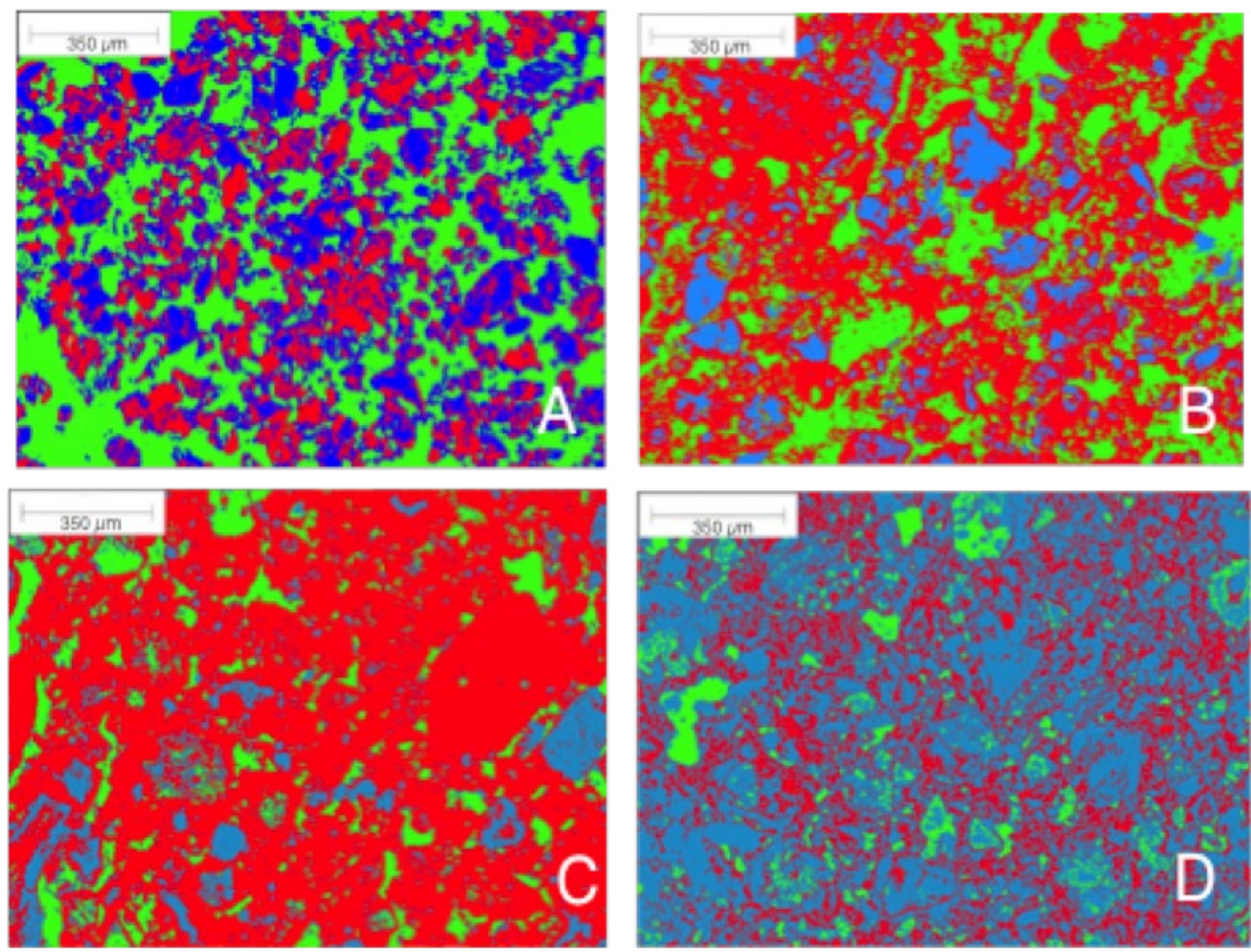

Figure 7. Images analyzed by the program Image Pro Plus 7.0. (A, B) - Thin sections from the profile BZII. A- 2C horizon not affected by the acid solution. B - 3C horizon affected by the acid solution. (C, D) samples from the soil columns) C- experimental column. D- non-experimental column. Red- ferruginous fine material, blue- pores and opaque components, green- other fine materials.

Table 6. Morphometrics results presenting averages and standard deviation of the contents of reddish fine material and other components (three points analyzed)

\begin{tabular}{lcc}
\multicolumn{1}{c}{ Sample } & $\begin{array}{c}\text { Ferruginous fine } \\
\text { material } \\
\%\end{array}$ & $\begin{array}{c}\text { Other components } \\
\%\end{array}$ \\
$\begin{array}{l}\text { Horizon } 2 \mathrm{C} \\
\text { Average }\end{array}$ & 36.2 & 63.4 \\
\hline Standard deviation & 2.9 & 2.59 \\
\hline $\begin{array}{l}\text { Horizon 3C } \\
\text { Average }\end{array}$ & 49.8 & 50.1 \\
\hline Standard deviation & 4.6 & 4.6 \\
\hline $\begin{array}{l}\text { Column without acid solution } \\
\text { Average }\end{array}$ & 29.03 & 70.96 \\
\hline Standard deviation & 17.52 & 17.52 \\
\hline $\begin{array}{l}\text { Column with acid solution } \\
\text { Average }\end{array}$ & 55.6 & 44.2 \\
\hline Standard deviation & 24.85 & 24.85
\end{tabular}


in the packing voids among sand particles we assume that they form the most vulnerable and easily transformable part of the carbonate pool. Calcite was identified together with quartz and plagioclase as a common mineral throughout the BZII profile except $3 \mathrm{C}$ (having signs of the mine spill). High (slightly alkaline) $\mathrm{pH}$ values of the non-affected soils are due to the presence of the carbonates.

Data on macroscopic changes, microscopic observations and chemical characteristics complement each other and together support an integral scenario of interaction between the soil matrix and acid solution. The major morphological change related to the effect of acid mine spill is the change of color of the affected soil horizons. Quantification of this change by colorimetric analysis showed the increase of $\mathrm{a}^{*}$ (red) and $\mathrm{b}^{*}$ (yellow) in the horizon 3C (BZII profile) and the experimental soil column and the color difference marked by the $\Delta \mathrm{E}^{*}$ between the samples influenced and not influenced by the acid solution.

The color has already been utilized as an indicator of acid sulfate soils and even of acid mine drainage, where the yellowish pigmentation was documented (Murad and Rojik 2003). Sánchez et al. (2015), who studied the color change in the soils influenced by the acid leachate from pyritic sediments, found that the soils changed color towards yellowish brown tones due to iron neoformation of ferruginous and sulfuric minerals, and linked it to the increase of concentrations of the elements: $\mathrm{Fe}$, $\mathrm{S}$, and $\mathrm{O}$. Among the precipitated components schwertmannite was studied which is substituted by jarosite under low $\mathrm{pH}$.

We further speculate the precipitation of $\mathrm{Fe}$ from the acid solution promoted the differences in color. The chemical data from the soil materials affected by acid solution have shown that the horizon $3 \mathrm{C}$ was enriched with $\mathrm{Fe}, \mathrm{As}, \mathrm{Cu}, \mathrm{Pb}$, and the soil of the experimental column with $\mathrm{Fe}$, $\mathrm{Cu}$ and $\mathrm{Mn}$. The precipitation of these elements is related to the presence of carbonates in the soil. It is known that interaction between this basic mineral and the acid solution from the mine neutralizes the acidity and retains the potentially toxic elements (USEPA 1998; lakovleva et al. 2015), although there is also possibility that the sorption process could retain these elements.
This interaction leads to the dissolution of the carbonates and the precipitation of gypsum, according to the following reaction:

$$
\begin{aligned}
& \text { (Reaction 1) } \\
& \mathrm{CaCO}_{3}
\end{aligned} \mathrm{H}_{2} \mathrm{SO}_{4} \rightarrow \mathrm{CaSO}_{4}+\mathrm{H}_{2} \mathrm{O}+\mathrm{CO}_{2}
$$

Iron is precipitated in the new mineralogical forms that were identified as ferrihydrite (Reaction 2), jarosite (Reaction 3) and schwertmannite (Reaction 4). The reactions involved are shown below:

$$
\begin{aligned}
& (\text { Reaction } 2) \mathrm{Fe}^{3+}+3 \mathrm{H}^{2} \mathrm{O} \rightarrow \mathrm{Fe}(\mathrm{OH})_{3}(\mathrm{~s})+\mathrm{H}^{+} \\
& \left(\text {Reaction 3) } \mathrm{K}++3 \mathrm{Fe}^{3+}+2 \mathrm{SO}_{4}{ }^{2-}+6 \mathrm{H}_{2} \mathrm{O} \rightarrow\right. \\
& \mathrm{KFe}_{3}\left(\mathrm{SO}_{4}\right)_{2}(\mathrm{OH})_{6}+6 \mathrm{H}^{+} \\
& \left(\text {Reaction 4) } 8 \mathrm{Fe}^{3+}+\mathrm{SO}_{4}{ }^{2-}+14 \mathrm{H}_{2} \mathrm{O} \rightarrow\right. \\
& \mathrm{Fe}_{8} \mathrm{O}_{8}(\mathrm{OH})_{6}\left(\mathrm{SO}_{4}\right)+22 \mathrm{H}^{+}
\end{aligned}
$$

This explanation received strong support from the micromorphological observations and morphometric analysis. In the thin sections from the soils affected by acid solution ( $3 \mathrm{C}$ horizon of the BZII profile and the experimental soil column) we registered a considerable increase of the reddish fine material colored with the ferruginous pigment. Its presence in the form of coatings on sand grains, bridges between them and microaggregates points to its recent neoformed character; also this type of microscopic distribution should produce the maximal pigmentation effect at macroscale. Morphometric study allowed to quantify this increase comparing the area occupied by red fine material in the affected and unaffected samples (Table 5): it was from about $13 \%$ when comparing $2 \mathrm{C}$ and $3 \mathrm{C}$ horizons of the BZII profile to $26 \%$ between the untreated and treated column samples.

Accumulation of the fine ferruginous components is accompanied by the precipitation of gypsum in the affected soils. The crystal morphology, intergrowth architecture and spatial distribution at the microscale leave no doubt about the neoformed character of gypsum. At the same time all carbonate components (both primary and secondary) disappear from the matrix. This agrees with the XRD results which did not register calcite and with slight lowering of $\mathrm{pH}$ : from 8 in the neighboring horizons to 7 in $3 \mathrm{C}$ in the BZII profile. 
We associate the increase of iron-rich fine material in the horizon $3 \mathrm{C}$ and even more in the experimental column with iron precipitated from the acid solution. It is known that iron is an element that precipitates after slight changes of $\mathrm{pH}$, above 3 , whereas the $3 \mathrm{C}$ horizon of the profile BZII presents $\mathrm{pH}$ that is imposed by the neutralization of acid solution by carbonates as discussed above. Thus the change of $\mathrm{pH}$ in the solution associated with the precipitation of gypsum and consumption of carbonates initiates precipitation of the iron. These changes are also found by Díaz et al. (2015) in a soil profile located $1 \mathrm{~km}$ away from BZII, he also reports a significant increase of fine ferruginous material associated with high concentrations of $\mathrm{Cu}, \mathrm{As}$, $\mathrm{Al}, \mathrm{Cd}, \mathrm{Cr}, \mathrm{Mn}$ and $\mathrm{Pb}$; these contaminants are supposed to co-precipitate together with the neoformed iron oxides (Marck and Leckie 1981; Marck et al. 1996)

We further speculate that this process could be responsible for early immobilization of the contaminants within the basin, so that soon after the catastrophic mine spill, high concentrations of contaminants were neither registered in groundwater nor in the surface waters of the low reaches of the Sonora river.

\section{Conclusions}

1) Interaction between the soils of the Sonora river basin and the acid mine solution in the natural environment and under laboratory conditions resulted in major mineralogical changes of soil matrix observed in thin sections: consumption of carbonates (both primary and secondary) and precipitation of neoformed crystalline gypsum and red fine material enriched in ferruginous components. These changes are linked to the chemical signals: increase of the content of $\mathrm{Fe}$ and heavy metal contaminants and lowering of $\mathrm{pH}$

2) The color changes are good indicators of the physical and chemical processes that occurred in the soils after their interaction with the acid solution, causing an increase in yellow $\left(b^{*}\right)$ and red $(a *)$ colorations, which is associated to the precipitation of iron oxides, which were identified with X-ray diffraction, mainly the formation of jarosite, ferrihydrite and schwertmannite.

\section{Acknowledgements}

We are grateful to the chemists Fabiola Vega García, Inés Ramos Bautista, Daniel Ramos Pérez, Astrid Vazquez Salado and Gerardo Martínez Jardines of the Environmental Geochemistry Laboratory, Rene Alcalá Martínez of the Soil Physics Laboratory and Javier Tadeo León of the Atomic Spectroscopy Laboratory for the support in the chemical and physical analyzes, Dr. Teresa Pi I Puig of the $X$-Ray Diffraction Laboratory for the support in x-ray diffraction, Dr. Lucy Mora Palomino of the Environmental Edaphology Laboratory for the support in the experiment of the column. All laboratories that are part of the National Laboratory of Geochemistry and Mineralogy (LANGEM) of Geology Institute, UNAM. 


\section{REFERENCES}

-ABC-Analitic. 2014. Informe de resultados del muetreo y análsis de agua, sedimentos y biota de los ríos Bacanuchi y Sonora contaminados por la fuga proveniente de la mina Buenavista del Cobre, hasta el de Septiembre. Laboratorios ABC Qúimica Investigación y Análisis S.A. de C. V. Septiembre 2014. 24 p.

- Bracamonte A, Lara B, Borbón M. 1997. El desarrollo de la industria minera sonorense: el retorno a la producción de metales preciosos. Región y Sociedad III:39-75.

- CONAGUA. 2018. Bases de datos climatológicos de Bacanuchi-Arizpe. http://conagua.gob.mx/tools/ RESOURCES/Max-Ext/00026007.TXT.

- Díaz OJ, Rivera UY, Sedov S, Solleiro RE. 2015. Micromorphogical evidences of the mine acid drainage in the soils of the Sonora River, Mexico. In: Resoration and reclamation of environmetal liabilities-technosols; 2015 Sep 20-25; Ciudad de México, Mexico City: The International conference of the working group on Soils in Urban, Industrial, Traffic and Minning Areas (Suitma 8).

- Flores DL, Alcalá MJR. 2010. Manual de Procedimientos Analíticos, Laboratorio de Fisica de Suelos. Departamento de Edafología, Instituto de Geología UNAM. 56 p. Available from: http://www.geologia.unam.mx/igl/deptos/ edafo/lfs/MANUAL\%20DEL\%20LABORATORIO\%20 DE\%20FISICA\%20DE\%20SUELOS1.pdf

- Gómez AA, Yocupicio AMT, Ortega RP. 1986. Concentraciones de $\mathrm{Cu}, \mathrm{Fe}, \mathrm{Mn}, \mathrm{Pb}$, y $\mathrm{Zn}$ en los sedimentos del río Sonora y de su afluente el Río Bacanuchi, Sonora, México. In: XXI Congreso Mexicano de Química Pura y Aplicada, Sección Química Ambiental; 1986 Sep 9-13; Cd. Oaxaca, Mexico; Bol Depto Geol UniSon; 1993, 10(1):49-62.

- Gómez AA, Yocupicio AMT, Ortega R. 1990. Niveles y distribución de metales pesados en el río Sonora y su afluente el río Bacanuchi, Sonora, Hermosillo. In: XXI Congreso Mexicano de Química Pura y Aplicada; 1989 Sep; Oaxaca, Oax, México; Ecología 1(2):10-20.

- Gutiérrez RME, Romero FM. 2015. Valoración ambiental de la Cuenca del Río Sonora, asociado al derrame del 06 de Agosto del 2014 de Buena Vista del Cobre. In: AIMMGM, XXXI Convención Internacional de Minería, Acapulco Gro, México; 2015 Oct 7-10; Acapulco, Guerrero México. p. 604-616.

- lakovleva E, Mäkilä E, Salonen J, Sitarz M, Wang, S. 2015. Acid mine drainage (AMD) treatment: neutralization and toxic elements removal with unmodified and modified limestone. Eco Eng. 81:30-40.

- Instituto Nacional de Estadística, Geografía e Informática (INEGI). 1993. Estudio Hidrológico del Estado de Sonora. Instituto Nacional de Estadística, Geografía e Informática. Gobierno del Estado de Sonora México: INEGI.
- IUSS Working Group WRB. 2015. World Reference Base for Soil Resources 2014, update 2015. International soil classification system for naming soils and creating legends for soil maps. World Soil Resources Reports No. 106. Rome: FAO.

- Krasilnikov P, Gutiérrez MCC, Ahrens RJ, Cruz COG, Sedov S, Solleiro ES. 2013. The Soils of Mexico. World Soils Book Series. New York, NY, USA: Springer.

- Mark MB, Leckie O. 1981. Multiple-site adsorption of $\mathrm{Cd}, \mathrm{Cu}, \mathrm{Zn}$ and $\mathrm{Pb}$ on amorphous iron oxy-hydroxide. $\mathrm{J}$ Colloid Interf Sci. 1:209-221.

- Mark MB, Sletten RS, Bailey RP, Bennett T. 1996. Sorption and filtration of metals using iron-oxide coated sand. Water Res. 11:2609-2620.

- Meinert LD. 1982. Skarn, manto, and breccia pipe formation in sedimentary rocks of the Cananea mining district, Sonora, Mexico. Econ Geol. 77:919-949.

- Morin AK, Hutt NM. 2001. Environmental geochemistry of minesite drainage: practical theory and case studies. Vancouver, British Columbia, Canada: MDAG Publishing.

- Murad E, Rojik P. 2003. Iron rich precipitates in a mine drainage environment: influence of $\mathrm{pH}$ mineralogy. Am Mineral. 88:1915-1918.

- Norma Oficial Mexicana NOM-127-SEMARNAT/SSA11994. Salud Ambiental. Agua para uso y consumo humano. Límites permisibles de calidad y tratamientos a que debe someterse el agua para su potabilización.

- Sánchez M, Romero FA, Martín PF. 2015. Soil-color changes by sulfurization induced from a pyritic surface sediment. Catena 135:173-183.

- Servicio Geológico Mexicano (SGM). 2008. Carta Geológico-minera de Cananea. (Escala 1:250000) H125. Pachuca Hgo, México: Servicio Geológico Mexicano.

- Singer DA, Berger VI, Moring BC. 2005. Porphyry copper deposits of the world: database, map, and grade and tonnage models. U. S. Geological Survey. Open file report 2005-1060. Available from: http://pubs.usgs.gov/ of/2005/1060/.

- Suppen N, Carranza M, Huerta M, Hernández M. 2006. Environmental management and life cycle approaches in the Mexican mining industry. J Clean Prod. 14(12):11011115.

- United States Environmental Protection Agency (USEPA). 1998. Permeable reactive barrier technologies for contaminant remediation. Washington, DC: U. S. Environmental Protection Agency. 102 p. Available from: p. https://clu-in.org/download/rtdf/prb/reactbar.pdf.

- Valencia MM, Ochoa LL, Noguez AB, Ruiz J, Pérez SE. 2006. Características metalogénicas de los depósitos de tipo pórfido cuprífero en México y su situación en el contexto mundial. B Soc Geol Mex. 1:1-26. 